\title{
Intrapsychic Factors Influencing Career Aspirations in College Women ${ }^{1}$
}

\author{
Jacquelynne E. Parsons ${ }^{2}$ \\ The University of Michigan \\ Irene H. Frieze \\ University of Pittsburgh \\ Diane N. Ruble \\ Princeton University
}

A 300-item questionnaire designed to assess the relationship and relative importance of several factors for women's career aspirations was answered by $169 \mathrm{fe}$ male college juniors and seniors. Regression analyses showed that women with high career aspirations were satisfied with their lives; confident of their career plans; willing to postpone marriage; nontraditional in their values and behaviors; generally external in orientation, believing that discrimination is responsible for many of women's failures and that organized pressure rather than individual action is necessary to combat this discrimination; certain that women's demands for equality are justified and that most men agree with them; likely to have had a working mother who was perceived as being dissatisfied with her own life; and if planning to marry soon, endorsing dual role compatability. When all variables were considered simultaneously, attitudinal factors were found to best predict career aspirations, while socialization variables were relatively unimportant.

\footnotetext{
${ }^{1}$ This study was supported by funds from the University of California, Los Angeles, Personality and Social Psychology Training Grant, USPHS $1 \mathrm{~T} 1 \mathrm{MH} \mathrm{11,696.} \mathrm{The} \mathrm{authors}$ wish to express their thanks to the Women's Studies Program at UCLA for its continued cooperation. Also deserving of recognition for their help with early phases of this study are Cathy Connor, Jomary Hilliard, Paula Johnson, Karen Paige, Andrea Tyree, and Gail Zellman. Portions of this paper were presented at the University of California, Los Angeles, Symposium on Sex Roles and Sex Differences, Los Angeles, 1972.

${ }^{2}$ All correspondence should be addressed to J. E. Parsons, Department of Psychology, the University of Michigan, 3433 Mason Hall, Ann Arbor, Michigan 48109.
} 
A number of psychological investigations have identified various factors which influence career aspirations of young women in such a way as to predetermine the training young women seek and the skills they acquire and thus perpetuate a system of women occupying lower status jobs than men. If society is to benefit from the unrealized career potential of women and if women are to enjoy new life options, it is important that efforts be made to overcome the effects of these factors. However, in order to do this it is necessary to more fully understand which of many factors are important in affecting career aspirations of college women. This study is concerned with variables relating to career aspirations of college women at a large metropolitan coeducational university. The focus is on four major areas: socialization, situational factors, attitudes, and personality characteristics. The effects of each factor individually and in comparison to the other factors are being investigated.

\section{Socialization Factors}

Most theorists cite the importance of the parents, especially the mother, in providing a model of appropriate adult behavior for the young girl (Angrist \& Almquist, 1975; Hoffman \& Nye, 1974; Mussen, 1969; O'Leary, 1974.) These beliefs about the female role, which develop in childhood, are thought to influence the personal role expectations of the college woman both in terms of her beliefs about acceptable roles for women and her assessment of her potential to fulfill nontraditional roles. Both of these assumptions have been borne out by empirical data (Hoffman \& Nye, 1974; Peterson, Note 1; Tangri, 1972; Vogel, Broverman, Broverman, Clarkson, \& Rosenkrantz, 1970). For example, Hoffman and Nye (1974) review several studies indicating that daughters of working mothers have a broader conception of the female role than do daughters of nonworking women. Consequently, college women whose mothers worked outside the home should have higher estimates of their own competence and potential for a professional career and, therefore, higher levels of aspirations.

It is also possible that women's perception of their mothers' satisfaction influences their role choices. Work by Baruch (1972) suggests that a daughter's acceptance of her mother's role for herself depends upon how satisfied she feels her mother is with that role. If this is true, then women should have lower career aspirations if they feel their mothers are satisfied with the primary role of homemaker. On the other hand, if their mothers are seen as dissatisfied with the role of homemaker, the women should have higher career aspirations. Likewise, women who perceive their employed mother as satisfied should have high career aspirations, while women who perceive their employed mother as dissatisfied may aspire to either the traditional role of wife and mother or to a career, but not to both. 


\section{Situational Factors}

Certain situational factors such as the availability of supportive institutions and the attitudes in the community also influence women's career aspirations (Nye \& Hoffman, 1963). These situational factors are reflected in college women's judgments and beliefs regarding the practicality of combining career and family roles and in their perception of peer support for dual career aspirations. Empirical evidence supports the importance of all three of these factors. Ample evidence indicates that role conflict does in fact have a negative effect on married women (see O'Leary, 1974, for a recent review of this literature). It is reasonable to assume that the degree of anticipated conflict should also influence a college woman's career aspirations. For example, Poloma's observations (Note 2; Poloma \& Garland, 1971) suggest that women's attitudes regarding the demands inherent in the wife-mother role will predict occupational aspirations. Higher career aspirations should occur where career obligations are not perceived as interfering with the fulfillment of wife-mother role demands. Therefore, it is predicted that a belief that facilitory institutions can lessen the burden of child care, without harming the child, will correlate postively with career aspirations. Alternatively, among women who do not feel that child care facilities are beneficial, high career aspirations should relate to rejection of the wife-mother role. Similarly, Angrist \& Almquist (1975), Barnett (1971), Hawley (1972), Lynch (1973), and Mathews and Tiedeman (1964) all provide evidence that the attitudes of one's peers influence career aspirations. Thus if college women feel their peers, especially their male peers, have negative attitudes toward women's career roles, they should have low career aspirations.

\section{Attitudes}

Attitudes reflecting the acceptance of the nonconscious ideology (Bem \& Bem, 1970) and attitudes reflecting the acceptance of the dominant group's prejudice against women (Allport, 1958; Korman, 1970; O'Leary, 1974) are also expected to influence women's career aspirations. Bem and Bem (1970) suggest that society, by use of subtle techniques of social influence, trains women to accept the traditional role ascribed to them. To the extent that a woman has accepted this nonconscious ideology and the related traditional values, she should have lower career aspirations either due to fear of success (Horner, 1971), to fear of loss of femininity (Lipman-Blumen, 1972; O'Leary, 1974; Tangri, 1972), to fear of an inability to fulfill the "primary" role ascribed to women (Epstein, 1971; Ginzberg, Ginzberg, Axelrod, \& Herma, 1951), or to a failure to even consider high level,typically masculine careers (Korman, 1970; O'Leary, 1974). 
The acceptance of the dominant group's prejudice toward women (Allport, 1958) should affect the career aspirations of college women through even more subtle and destructive mechanisms. Since the dominant group - in this case men - views women as basically incompetent and inferior (Broverman, Vogel, Broverman, Clarkson, \& Rosenkrantz, 1972; Goldberg, 1968; Kaley, 1971; McKee \& Sherrifs, 1957), the acceptance of this prejudice should lead to the belief by women that women in general are inferior, incapable of handling positions of authority, and that the individual woman should lower her own career aspirations.

\section{Personality Factors}

Personality factors have also been shown to affect women's career aspirations (Barnett, 1971). Several locus of control scores (Gurin, Gurin, Lao, \& Beattie, 1969) or beliefs about causality are expected to predict level of aspiration. Although these relationships have not been fully investigated for women, there is evidence that for Blacks, high internality (strong belief that one's successes and failures are caused by oneself) may lead to excessive self-blame in failure situations. Rejection and failure may be experienced by many women in career situations. Gurin et al. (1969) suggest that for a minority group facing societal opposition and therefore increased failure, an external orientation for failure might lead to less self-blame, higher self-esteem, and an increased desire to assume nontraditional roles. We propose that, in the area of career aspirations, such an external orientation may have similar benefical effects on women.

\section{Summary}

It is predicted that several types of variables will be related to career aspirations in college women. The focus of this study is to assess the effects of each of these variables so that some determination can be made regarding their relative importance for college women today.

\section{METHOD}

\section{Sample}

The sample consisted of 169 junior and senior women from four women's studies classes (psychology, history, English, and an introduction to women's liberation class) and from an upper division developmental psychology class at the University of California, Los Angeles. Juniors and seniors from these classes 
were selected because previous research has found large differences in women's career aspirations between the early and later years in college (Angrist \& Almquist, 1975) and because it was believed that decisions and beliefs regarding dual roles and careers would be especially salient for these women. Both the women's studies classes and the developmental psychology class were used to ensure a range of attitudes and aspirations.

\section{Questionnaire}

A questionnaire consisting of approximately 300 items $^{3}$ was distributed on the first day of class during the winter quarter of 1971-1972 as part of a larger study - an evaluation of the impact of the women's studies courses upon their students (reported in Ruble, Croke, Frieze, \& Parsons, 1975). Since the questionnaires were quite lengthy, the students were allowed to take portions of them home and return them during the first week of classes. Approximately $60 \%$ of the entire sample returned completed questionnaires. The questionnaire included items designed to tap career aspirations, certainty of career plans, plans for future wife and mother roles, attitudes toward women's and men's roles in the family, mother and father's career history, beliefs regarding societal support systems, acceptance of dominant group prejudice (self-hatred), and locus of control.

\section{Variables}

All items, except the Locus of Control scale, on the questionnaire were factor analyzed. When an eigenvalue of 1.5 was used as a stop criterion, 11 interpretable factors were obtained. An orthogonal varimax rotation was done for the 11 factors. On the basis of this rotation summary scores were created by summing all variables loading over 35 within each of 7 factors: Level of Aspiration (LOA), Family Socioeconomic Status (SES), Mother's Career (MOCAREER), Dual Role Compatibility (ROLEC), Self-Hatred (SELFH), Nontraditional Behavior (NTRADB), and Traditional Values (TRADV). ${ }^{4}$

LOA was the major dependent variable for this study. It consisted of the following items: plans for future education, expected annual income at 40 , percentage of time during the years from age 25 to 65 expected to be devoted to work. Independent variables (including both summary scores and several single items) were divided into three categories: (1) demographics - age, marital status,

\footnotetext{
${ }^{3}$ Approximately half of the items were contributed by Karen Paige, U. C. Davis and Survey Research Center, Berkeley, California.

${ }^{4}$ Items comprising each of these summary variables - along with their means, standard deviations, and intercorrelations - can be obtained from the first author.
} 
number of children, race, grade point average, SES, and MOCAREER; (2) attitudes - ROLEC, SELFH, NTRADB, TRADV, and a series of single items tapping beliefs regarding one's own support for women's demands; male and female peers' support for women's demands; certainty of career plans; marriage plans; perceived maternal life satisfaction; own life satisfaction; and identification with the women's movement; and (3) personality variables - subscores from a modification of Gurin et al.'s I-E scale (1969) which replaced items referring to Blacks with the same item referring to women. ${ }^{5}$

\section{RESULTS}

\section{General Characteristics of the Sample}

In general the sample tended to report relatively high career aspirations and nontraditional orientations towards women's roles. For example, $62 \%$ wanted to obtain a graduate degree, although many wanted jobs in traditional fields such as teaching. Of the total group $70 \%$ planned to work all or most of their adult lives, and $60 \%$ were certain of their career plans.

The sample was generally White (70\% of European background) and upper middle class (average annual income of parents was between $\$ 16,000$ and $\$ 20,000)$. Most of the mothers had not worked, and those who had tended to have low level jobs. And finally, self-hatred was virtually nonexistent in this sample and thus was not included in further analyses.

\section{Multiple Regression Predictors of LOA}

A stepwise multiple regression analysis was performed to determine which of the variables used in the study would best predict LOA. Using a stop criterion of a change in multiple $R^{2}$ of less than $.01,9$ variables were found to predict $34 \%$ of the variance in LOA (Table I). The strongest predictor was the belief that women's demands for equality are justified. Other attitudinal and belief variables entering the equation were certainty of career plans, nontraditional behavior (NTRADB), the desire to delay marriage, and the belief that men feel women's demands for equality are justified. Three of the personality scales also emerged as predictors: the belief in the necessity for group rather than individual action to combat discrimination, the belief that the system rather than the individual is responsible for failure, and the belief that one's life is not under personal control. Membership in a minority racial group was the only demographic variable predicting LOA.

${ }^{s}$ Specific personality scales can be obtained from the first author. 
Table I. Multiple Regression Analyses: All Variables Combined to Predict Level of Aspiration

\begin{tabular}{|c|c|c|c|c|}
\hline Variables in equation & $B$ & $\begin{array}{l}\text { Multiple } \\
\quad R \\
\end{array}$ & $\begin{array}{c}\text { Multiple } \\
R^{2} \\
\end{array}$ & $\underset{R}{\text { Simple }}$ \\
\hline $\begin{array}{l}\text { Belief that women's demands for } \\
\text { equality are justified }\end{array}$ & .35 & .34 & .11 & .34 \\
\hline Certainty of career plans & .20 & .45 & .20 & .28 \\
\hline Nontraditional behavior & .44 & .49 & .24 & .30 \\
\hline $\begin{array}{l}\text { Belief in group rather than } \\
\text { individual action to combat } \\
\text { discrimination }\end{array}$ & .11 & .52 & .27 & .31 \\
\hline $\begin{array}{l}\text { Belief that the system rather than } \\
\text { the individual is to blame for } \\
\text { failures }\end{array}$ & -.01 & .54 & .29 & .12 \\
\hline Desire to delay marriage & .04 & .55 & .30 & .20 \\
\hline $\begin{array}{l}\text { Belief that men feel women's } \\
\text { demands for equality are } \\
\text { justified }\end{array}$ & .19 & .56 & .31 & .07 \\
\hline Minority racial group & .17 & .57 & .32 & .01 \\
\hline $\begin{array}{l}\text { Belief that one's own life is not } \\
\text { under personal control }\end{array}$ & .01 & .58 & .34 & -.12 \\
\hline
\end{tabular}

The relative importance of attitudinal and belief variables in predicting LOA was also seen in the fact that these variables predicted $27 \%$ of the variance, while demographics predicted only $6 \%$ of the variance and personality measures predicted $15 \%$ of the variance. Socialization factors were unimportant and did not yield a significant multiple $R^{2}$.

\section{Chi-Square Analyses}

To test specific hypotheses, LOA was divided into high and low scores and crossed with dichotomous forms of the appropriate independent variables. ${ }^{6}$ While father's career level as reflected by SES was not significantly related to LOA, mother's career orientation was related to higher $\operatorname{LOA}\left(\chi^{2}=3.57, p<.10\right)$.

The effects of the mother's career were hypothesized to be mediated by the mother's satisfaction with her work. Although there was no direct measure of maternal career satisfaction, general maternal satisfaction was assessed with an item measuring perceived satisfaction of mother. Since most mothers did not work, career aspirations were expected to be negatively related to maternal satisfaction, and this was the case $\left(\chi^{2}=6.51, p<.05\right)$. To directly test the hypothesized mediating effect, a $2 \times 2 \times 2$ table was constructed for levels of aspiration, maternal career levels, and maternal satisfaction. Results indicated that ${ }^{6}$ Specific $\chi^{2}$ tables can be obtained from the first author. 
given high perceived maternal satisfaction, LOA was not related to the mother's career. But when mothers were perceived as dissatisfied, career aspirations were higher in general, especially if the mother had worked $\left(\chi^{2}=4.91, p<.05\right)$. When levels of aspiration were directly compared, the group whose mothers had worked and were dissatisfied had significantly higher LOA than women whose mothers did not work and were satisfied $\left(\chi^{2}=12.8, p<.001\right)$.

Situational Factors. Only one of the three variables used to assess the relationship between peer support and career aspiration yielded a marginally significant $\chi^{2}$. Women who identified with the women's liberation movement tended to have a higher $\operatorname{LOA}\left(\chi^{2}=3.16, p<.10\right)$.

A second set of situational hypotheses were related to the belief in the compatibility of the dual wife-mother and career woman roles (ROLEC). Although ROLEC alone did not relate significantly to LOA, beliefs in role compatibility were found to be related to LOA when crossed with the desire to delay marriage. As predicted, among women who had a low belief in dual role compatibility, high LOA was related to rejection of marriage and low LOA was related to early plans to marry $\left(\chi^{2}=8.20, p<.01\right)$. A similar relationship held for women with high beliefs in role compatibility ( $r=.26$ as compared to $r=.34$ ) This result may be partially the result of the strong relationship of the desire to delay or reject marriage and LOA $\left(\chi^{2}=16.01, p<.001\right)$.

Attitudinal and Personality Factors. Nontraditional values were significantly related to LOA as predicted $\left(\chi^{2}=4.52, p<.05\right)$. Women holding nontraditional beliefs had higher LOA. Although not predicted, women who felt more satisfaction with their lives also tended to have higher LOA $\left(\chi^{2}=4.01\right.$, $p<.05)$.

Many of the I-E subscales were related to LOA. Chi-square analyses indicated that the overall belief that events are under external control $\left(\chi^{2}=5.92\right.$, $p<.02)$, the belief that events are not under the control of the individual $\left(\chi^{2}=3.85, p<.05\right)$, the belief that group rather than individual action is necessary to combat discrimination $\left(\chi^{2}=6.37, p<.02\right)$ and the belief that discrimination is responsible for many failures of women $\left(\chi^{2}=4.79, p<.05\right)$ were related to LOA as predicted, with more external scores relating to higher career aspirations.

\section{DISCUSSION}

Results indicated that many factors were related to a desire for a career in college women. Summarizing all results, the woman with high career aspirations is satisfied with her life, confident of her career plans, and willing to postpone marriage. She is nontraditional in her values and behaves in nonconventional ways. She believes that neither she personally nor people in general have control over their environments. She believes that organized pressure rather than 
individual action is necessary to combat discrimination and that discrimination is responsible for many of the failures of women, and she is somewhat more likely to identify with the women's liberation movement. She believes that a woman's demands for equality are justified and that most men agree with her on this issue.

The regression analyses indicated that, in general, attitudinal and personality variables were more related to levels of aspiration in college women than were either demographic or socialization variables. Situational factors such as the perception of how men feel about women's demands for equality and variables mediating the effects of situational factors (certainty of career plans and desire to delay marriage) were particularly important predietors of LOA along with several of the personality scales.

Looking at specific hypotheses, socialization factors were only marginally related to LOA. Mothers with careers and mothers who were dissatisfied with their lives tended to have college-age daughters with higher career aspirations. As expected, women with satisfied mothers who did not work tended to have especially low aspirations. Unexpectedly, dissatisfaction in mothers who worked was also related to higher LOA. This latter result may have been due to the generally low level jobs held by the mothers, many of whom were college educated. These women may have been very dissatisfied with the types of jobs they were able to obtain and therefore encouraged their daughters to achieve as they had not been able to. But, in general, socialization factors were not highly related to LOA, perhaps because of the restricted range of socialization experiences to which this sample of college women at a large university had been exposed or perhaps because situational and personality factors are more important determinants of achievement for educated women.

Male peer support was found to be an important predictor of high LOA in the regression equations, but in general the support of women for women's demands for equality was not related to LOA in regression nor $2 \times 2$ chi-square analyses. It was predicted that male support would be more relevant for this group of marriageable women, as was found. There was evidence of peer support of women leading to higher LOA - specifically for women who were members of a supportive peer group, the womens' liberation movement. Also, regression equations showed that women who felt that women's demands for equality were justified and who also felt the peer support of men for this belief were especially likely to have high LOA. These results support the hypothesis that supportive peer groups are important for women who desire a career and suggest that more such groups are needed for college women.

Although the total score variable of belief in the compatibility of the dual role of wife/mother and career woman, a second situational variable, related only marginally to LOA, other results suggest that many women are concerned with possible role strain. In this sample women with high career goals wanted to delay marriage, especially if they believed in dual role incompatibility. If the 
general level of women's aspitations is to rise, society must therefore seek both to re-educate women regarding the compatibility of their roles (Bernard, 1971, presents evidence that many women with families who work are very happy doing so) and to provide institutions such as child care facilities and maternity leave which will serve to reduce the realistic strain many women feel when attempting to combine dual roles. Also, having more women in professional jobs might provide role models for successful combinations of dual roles for younger women who are considering the advisability of training for a future career.

Attitudinal and personality factors were highly related to LOA. In general, personality variables were found to relate to career aspirations as predicted, with women higher in externality having higher LOA. Both nontraditional values and nontraditional behavior (or activism) were related to higher career aspirations in our sample. Since having a career is also a form of nontraditional behavior, it was not clear if all three variables were related to some common underlying causal factor - that is, if women with nontraditional values are able to more easily consider a career rather than a traditional role - or if women who had high achievement needs by necessity become nontraditional, since there is so little opportunity for expression of achievement needs within traditional roles. The causal interrelationships of these variables need further study.

\section{REFERENCE NOTES}

1. Peterson, E. T. The impact of maternal employment on the mother-daughter relationship and the daughter's role-orientation. Unpublished doctoral dissertation, University of Michigan, 1950.

2. Poloma, M. H. The myth of the egalitarian family: Familial roles and the professionally employed wife. Paper presented at the annual meeting of the American Sociological Association, Washington, D.C., 1970.

\section{REFERENCES}

Allport, G. The nature of prejudice. New York: Doubleday, 1958.

Angrist, S. S., \& Almquist, E. M. Careers and contingencies. New York: Dunellen, 1975.

Bamett, R. Personality correlates of vocational planning in women. Genetic Psychology Monographs, 1971, 83, 309-356.

Baruch, G. K. Maternal influences upon college women's attitudes toward women and work. Developmental Psychology, 1972, 6, 32-37.

Bem, S., \& Bem, D. Case study of a nonconscious ideology: Training the woman to know her place. In D. Bem (Ed.), Beliefs, attitudes and human affairs. Belmont, Calif.: Brooks/Cole, 1970.

Bernard, J. Women and the public interest. Chicago: Aldine-Atherton, 1971.

Broverman, I. K., Vogel, S. R., Broverman, D. M., Clarkson, F. M., \& Rosenkrantz, P. S. Sex-role stereotypes: A current appraisal. Journal of Social Issues, 1972, 28, 59-78.

Epstein, C. F. Woman's place. Berkeley: University of California Press, 1971.

Ginzberg, E., Ginzberg, S., Axelrod, S., \& Herma, J. Occupational clinic: An approach to a general theory. New York: Columbia University Press, 1951. 
Goldberg, P. Are women prejudiced against women? Transaction, 1968, 5, 28-30.

Gurin, P., Gurin, G., Loa, R. C., \& Beattie, M. Internal-external control in the motivational dynamics of Negro youth. Journal of Social lssues, 1969, 15, 29-53.

Hawley, P. Perception of male models of femininity related to career choice. Journal of Counseling Psychology, 1972, 19, 308-313.

Hoffman, L. W., \& Nye, F. I. Working mothers, San Francisco: Jossey-Bass Publishers, 1974.

Horner, M. S. Femininity and successful achievement: A basic inconsistency. In M. H. Garsk of (Ed.), Roles women play: Readings toward women's liberation. Belmont, Calif.: Brooks/Cole, 1971.

Kaley, M. M. Attitudes toward the dual role of the married professional woman. American Psychologist, 1971, 26, 301-306.

Korman, H. K. Toward a hypothesis of work behavior. Journal of Applied Psychology, 1970, $54,31-41$.

Lipman-Blumen, J. How ideology shapes women's lives. Scientific American, 1972, 226, 34 42.

Lynch, E. M. The executive suite: Feminine style. New York: Amacom, 1973.

Mathews, E., \& Tiedeman, D. Attitudes toward career and marriage and the development of life style in young women. Journal of Counseling Psychology, 1964, 2, 375-384.

McKee, J. P., \& Sherrifs, A. C. The differential evaluation of males and females. Journal of Personality, 1957, 25, 356-371.

McKee, J. P., \& Sherrifs, A. C. Men's and women's beliefs, ideals and self concepts. American Journal of Sociology, 1959, 64, 356-363.

Mussen, H. Early sex-role development. In D. A. Goslin (Ed.), Handbook of socialization theory and research. Chicago: Rand McNally, 1969.

Nye, F., \& Hoffman, L. W. The employed mother in America. Chicago: Rand McNally, 1963.

O'Leary, V. E. Some attitudinal barriers to occupational aspirations in women. Psychological Bulletin, 1974, 81, 809-826.

Poloma, M. H., \& Garland, T. W. Jobs or careers? The case of the professionally employed married woman in Europe and America. International Journal of Comparative Sociology, 1971, 33, Part II, 531-540.

Ruble, D. N., Croke, J. A., Frieze, I., \& Parsons, J. E. A field study of sex-role attitude change in college women. Journal of Applied Social Psychology, 1975, 5, 110-117.

Tangri, S. S. Determinants of occupational role innovation among college women. Journal of Social Issues, 1972, 28, 177-200.

Vogel, S. R., Broverman, I. K., Broverman, D. H., Clarkson, F. E., \& Rosenkrantz, P. S. Maternal employment and perception of sex roles among college students. Developmental Psychology, 1970, 3, 384-391. 